Sandra Stojadinović Jovanović 1

University of Belgrade, Faculty of Economics
SCIENTIFIC REVIEW ARTICLE

doi:10.5937/ekonomika1602049S

Received: April 5, 2016

Accepted: May 9, 2016

\title{
INTERDEPENDENCE OF INTERNATIONAL TRADE AND INVESTMENT FLOWS IN THE POST-CRISIS PERIOD ${ }^{2}$
}

\begin{abstract}
The world economy was characterized by the continuous increase of international trade and international investments flows in the second half of the twentieth century and by intertwining of these flows especially in the period after 1990s. The aim of the paper is to show that there are mutual relationship, interconnection and intertwining of international trade flows and investment flows in the post-crisis period as well as in the period before the 2008 crisis. The post-crisis period has brought the recovery of both international trade flows and international investment flows and their higher levels. These developments haven't changed the fact that, the same as in the period before the crisis, international trade flows continue to perform increasingly more through investments flows, that is through foreign affiliates'sales, then through classic, cross-border trade. The sales through foreign affiliates remain the main channel of international trading. In this situation, only the approach that means the new coverage implementation of international trade flows will lead us to the real international trade values and international trade picture. If we look for the impetus and drivers of the economic growth in trade and investments flows, then we must take into account the connection and intertwining of these two types of flows in order to have a real picture of them and make adequate decisions in the field of investment, trade and economic policy.
\end{abstract}

Key words: international trade, international investments, foreign direct investments, foreign affiliates'sales.

JEL classification: F10, F21, F23.

\section{МЕЂУЗАВИСНОСТ МЕЪУНАРОДНИХ ТРГОВИНСКИХ И ИНВЕСТИЦИОНИХ ТОКОВА У ПОСТКРИЗНОМ ПЕРИОДУ}

\begin{abstract}
Апстракт
Светску привреду је карактерисао континуирани пораст међународних трговинских и инвестиционих токова у другој половини ХХ века као и испреплетаност

\footnotetext{
${ }^{1}$ sandra@ekof.bg.ac.rs

${ }^{2}$ The paper is the result of the research done as a part of the project no. 179062 "Contemporary Management and Marketing Methods in Improving Competitiveness of Companies in Serbia in the Process of its Integration in European Union" financed by the Ministry of Education, Science and Technological Development of the Republic of Serbia.
} 
ових токова нарочито у периоду после 1990-тих година. Циь рада је да покаже да постоји међусобни однос, повезаност и испреплетаност међународних трговинских и инвестиционих токова у посткризном периоду као и у периоду пре кризе из 2008. године. Посткризни период је донео опоравак како међународних трговинских тако и међународних инвестиционих токова, као и юихове веће обиме. Овакав развој није променио чињеницу да се, исто као и у периоду пре кризе, међународни трговински токови све више одвијају кроз инвестиционе токове, односно кроз продаје страних филијала, него кроз класичну трговину која се одвија преко националних граница. Продаје посредством страних филијала остају главни канал међународног трговања. У оваквој ситуацији, само приступ који подразумева примену новог обухвата међународних трговинских токова ће нас водити до стварних вредности и праве слике међународне трговине. Ако подстицаје и покретаче економског раста тражимо у трговини и инвестицијама, онда морамо узети у обзир повезаност и испреплетаност ових токова како би имали праву слику о њима и доносили адекватне одлуке на пољу инвестиционе, трговинске и економске политике.

Кьучне речи: међународна трговина, међународне инвестиције, стране директне инвестиције, продаје страних филијала.

\section{Introduction}

The world economy was characterized by the continuous increase of international trade flows and international investments flows, primarily foreign direct investment flows, in the second half of the twentieth century. International trade has grown dynamically since the second half of the twentieth century. Its values are measured in figures of over 10 trillion USD since 2005. The most important segment of international trade represents international merchandise trade (which accounts for about $80 \%$ of world trade) which tremendous growth, during the entire second half of the twentieth century and early twenty-first century, led to achieving significantly higher growth rate of world trade relative to the growth rate of world production (based on data from: WTO, 1995; WTO, 2004, p. 17; WTO, 2007, p. 7; WTO, 2013 , p. 19). Since the 1950 s to the early twenty-first century, the value of international merchandise trade has increased over 100 times: from 1948 to 2008 its value has increased from 58 billion USD to over 16 trillion USD i.e. for 208 times, and from 1948 to 2011 (when international trade reaches record value) its value has increased for 314 times (Figure 1).

Figure 1: Growth of international merchandise trade (billion USD)

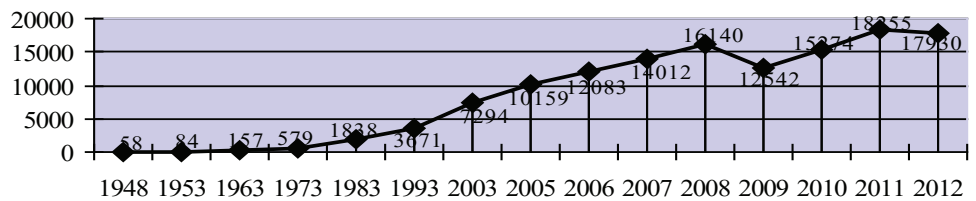

Source: Author's graphic presentation of the data from (WTO, 2004, p. 30; WTO, 2007, p. 175; WTO, 2012, p. 209 and WTO, 2013, p. 22). 
In the first decade of the twenty-first century, international merchandise trade recorded a continuous increase until 2008, when the world merchandise exports reached its first record value of 16 trillion USD. Due to the 2008 global economic crisis, international merchandise trade recorded its biggest decline since the mid twentieth century, for $22 \%$ compared to 2008 , to a level of 12.5 trillion USD in 2009 . This decline was accompanied by a sharp rebound in 2010 to 15.3 trillion USD. The growing trend continued in 2011, when international merchandise trade reached its highest value ever of 18.2 trillion USD. The value of almost 18 trillion USD the international trade also maintained in 2012.

As well as international trade, foreign direct investment flows have also been dynamically rising since the second half of the twentieth century. The last decade of the twentieth century was the period of the greatest FDI growth. From 1990 to 2000, total FDI inflows have increased seven times (from 0.2 trillion USD to 1.4 trillion USD) reaching its highest value until then (Figure 2).

Figure 2: Growth of world FDI inflows (billion USD)

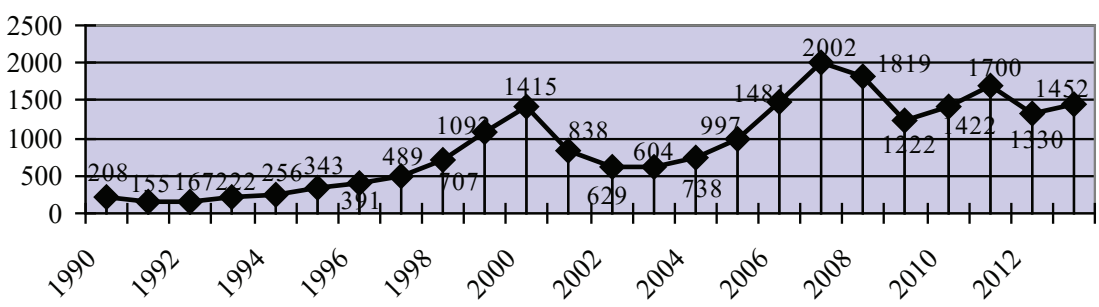

Source: Author's graphic presentation of the data from UNCTAD FDI database.

After its first record value in 2000, world FDI inflows have recorded a decline for three consecutive years (until 2003), and then four consecutive years of growth and in 2007 reached the highest value ever - over 2 trillion USD. Global economic and financial crisis in the second half of 2007 was followed by the shifts of falls and increases in world FDI inflows.

From the peak in 2007, FDI inflows declined rapidly to 1.2 trillion USD in 2009. The 2009 decline was followed by FDI inflows growth in 2010 and 2011 (to 1.4 and then to 1.7 trillion USD), surpassing the first record level of 2000. What followed was again the sharp drop of FDI in 2012 (on 1.3 trillion USD), and then rebound in 2013 to 1.45 trillion USD, reaching the level of 2010. FDI inflows in 2013 rose in all three groups of countries (developed, developing and transition countries) but to varying degrees. According to the UNCTAD's projection (UNCTAD, 2014, p. ix) it can be expected that the realized value of FDI flows in 2014 will amount to 1.6 trillion USD, and that FDI flows will grow to 1.75 trillion USD in 2015 and to 1.85 trillion USD in 2016.

Expansion of international trade and FDI flows dragged the world economic growth. From the second half of the $20^{\text {th }}$ century onwards they represented a lever of world growth. The data about their movement and the former analysis are based on the official trade and FDI figures. However, the aim of the paper is to show that beside this analysis based on the official trade and FDI figures, there are mutual interconnection and intertwining of international trade flows and investment flows that also should be taken 
into account in the analysis of the world trade. There are mutual interconnection and intertwining of international trade flows and investment flows in the post-crisis period as well as in the period before the crisis, but within the different values of international trade and international investments in these periods, which must be taken into account when we do the analysis.

The post-crisis period has brought the recovery of both international trade flows and international investment flows and their higher levels. These developments haven't changed the fact that the same as in the period before the crisis, international trade flows continue to perform increasingly more through investments flows, that is through foreign affiliates' sales which are results of foreign direct investment flows, then through classic, cross-border trade. The sales through foreign affiliates remain the main channel of international trading.

Therefore, the paper accentuates the need for the recognition of this intertwining of international trade flows and international investment flows and also the apprehension of prevailing realization of international trade through foreign affiliates' sales as well as the resulting need for the international trade analysis and calculation of international trade values different from the classical one. Only this approach, only the approach that means the new coverage implementation of international trade flows, will lead us to the different but realistic international trade values and international trade picture. The following part of the paper will give the literature review about FDI and international trade and their relation indicating that their relation (either substitute or complementary) must influence our analysis of international trade and FDI. The second part of the paper explains interconnection and intertwining of international trade and investment flows, showing the results of application of the new approach and coverage of international trade flows.

\section{Literature Review}

The literature about FDI is broad. A systematic review of the literature on FDI, its determinants and motives is given by Blonigen (2005). Empirical studies and theoretical models dealing with FDI may be also classified into: early studies of FDI as well as FDI in the context of neoclassical trade theory, ownership advantages, aggregate variables, OLI framework, proximity-concentration and factor-proportions hypothesis, knowledge-capital model, risk diversification models and policy variables (Faeth, 2009). These approaches are not mutually exclusive, but rather complement each other explaining various aspects of FDI. One of the main theoretical approaches, Dunning OLI paradigm (Dunning, 2000), explains that the reasons for FDI undertaking may be found in (Ownership, Location or Internalization) advantages which company/investor may achieve through direct investing abroad.

Also the literature about the relation between international trade and foreign direct investments is broad. The views and approaches about this relationship are different. According to Vernon (1966), the trade and FDI may be seen as successive stages in firm's production for foreign markets, whereby the firm would decide to invest abroad when trade no longer allows it to capture the rents from its assets. According to Hymer (1976), the production process will be organized through subsidiaries in order to capture the 
rents from firm-specific assets including advanced technology, managerial, marketing and distributional skills. The analysis of FDI and trade at the aggregate level is provided through the inclusion of FDI dimension in the flying geese paradigm by Kojima (1973a), who distinguished pro-trade FDI and anti-trade FDI. In the model, FDI is trade-oriented and complementary to the host country's economy. There are other studies (Kojima, 1973b; Kojima, 1982; Kojima and Ozawa, 1984; Ozawa, 1990, Ozawa, 1992 and Ozawa, 1995) which also explain the pattern of FDI in the similar way. Mismatch can be observed in literature views between findings of complementary relationship and theoretical premise of substitute relationship between FDI and trade. The traditional theory of multinational corporation finds substitution of FDI and trade. Some empirical studies on the relationship between trade and FDI do not provide conclusive results (Agarwal, 1980; Hufbauer, Lakdawalla and Malani, 1994). Other empirical studies find complementary relation (Lipsey and Weiss, 1984; Clausing, 2000; Head and Ries, 2001; Broadman, 2005). Blonigen (2001) finds evidence for both substitution and complementarity between foreign production and exports.

However, the different studies about relation between FDI and trade do not indicated how that relation (either substitute or complementary) should influence our analysis of international trade and FDI. Our analysis of international trade and FDI is based on the official trade figures and official FDI figures which are result of existing methodology of international trade statistics and FDI statistics. The official trade statistics gives us the figures on the value of international trade and foreign trade of individual countries, basing its measuring of trade flows primarily ${ }^{3}$ on the coverage of classis trade transactions taking place across national borders. Application of existing methodology results in existing official trade figures and existing official investment (FDI) figures.

As the dominant channel of international trading in contemporary world trade foreign affiliate sales - is not included in official trade figures, a great deal of global trade is missing from the reported trade figures. The comprehension and analysis of contemporary international trade must be changed, because modern trade flows take place both as classic cross-border trade flows and via FDI flows. Because of that the international trade can no longer be analyzed classically, as cross-border trade only; instead, we must expand it, register it statistically, calculate its value and analyze it in the new way.

If we apply a new approach in the international trade analysis (Stojadinović Jovanović, 2010) and the new coverage of international trade flows, we will get the different values of the whole, world trade as well as of the foreign trade of individual countries. The applied methodology is based on FATS methodology (presented in UN et al., 2002 and UN et al., 2010) covering sales of TNCs' foreign affiliates and on a proposal for the new coverage of international trade flows (Stojadinović Jovanović, 2013) which suggests the inclusion of foreign affiliates' sales as a main trading channel in contemporary world economy in international trade coverage, calculation and analysis. Based on this methodology, the paper will approach in the same way to the analysis of the international trade flows and investment flows in the post crisis period. It will show that there is intertwining of international trade flows and investment flows in the post-crisis period, the same as in the period before the crisis. It will also show that the implementation of the new way of calculation of the world trade will result in the new world trade values, higher than the existing one, in case of post-crisis period as well as in the pre-crisis period. 


\section{Intertwining of International Trade and Investment Flows}

The rise of international trade since the second half of the twentieth century was associated with the growth of transnational companies (TNCs), increasing undertaking of foreign direct investments (FDIs) by TNCs and expansion of their affiliates abroad. The rise of foreign direct investments (FDIs) in the world economy led to the expansion of foreign affiliates' production (international production) and foreign affiliates' sales. Undertaking direct investments abroad include establishing foreign affiliates for performing production in them (international production) with the aim to sell the manufactured goods and services on local market and markets of other countries. Up to the 1990s the sales of foreign affiliates and the world export were almost equal (Table 1). But after 1990 firms started to export more through foreign affiliates which are the result of foreign direct investments than through traditional, cross-border exportation. Thus, after the 1990s the sales of foreign affiliates accomplished faster growth and much higher value (almost double in some years) than the world export and exporting through foreign affiliates and foreign direct investments has become more important channel of trading than traditional exporting.

The period after the $1990 \mathrm{~s}$ is the period when the significant changes happened regarding the way the international trade flows perform, caused by the expansion of investment (FDI) flows and resulting expansion of number and activities of foreign affiliates and their international production. The sales of foreign affiliates increased worldwide from 2.7 trillion USD in 1982 to 6.1 trillion USD in 1990 and to 31 trillion USD in 2007 and 33 trillion USD in 2008 (Table 1). At the same time, these sales of foreign affiliates were much higher than the world exports, showing that companies sold more through foreign affiliates than trough classic, direct, cross-border export registered by official international trade statistics as the world export. However, the outstanding sales of foreign affiliates are not covered and not included in official trade figures.

Table 1: The forms of international trading

\begin{tabular}{|c|c|c|c|}
\hline \multirow{2}{*}{} & \multicolumn{2}{|c|}{ Value at current prices (billions of dollars) } & $\begin{array}{c}\text { The presence of the } \\
\text { international trading } \\
\text { forms (1):(2) }\end{array}$ \\
\cline { 2 - 4 } & Sales of foreign affiliates (1) & World exports of goods and services (2) & $1.14: 1$ \\
\hline 1982 & 2741 & 2395 & $1.39: 1$ \\
\hline 1990 & 6126 & 4417 & $2.23: 1$ \\
\hline 2000 & 15680 & 7036 & $2.49: 1$ \\
\hline 2001 & 18517 & 7430 & $2.26: 1$ \\
\hline 2002 & 17685 & 7838 & $1.91: 1$ \\
\hline 2003 & 17580 & 9228 & $1.87: 1$ \\
\hline 2004 & 20986 & 11196 & $1.75: 1$ \\
\hline 2005 & 22171 & 12641 & $1.74: 1$ \\
\hline 2006 & 25844 & 14848 & $1.82: 1$ \\
\hline 2007 & 31197 & 17138 & $1.91: 1$ \\
\hline 2008 & 33300 & 19794 & $1.76: 1$ \\
\hline 2009 & 30213 & 15783 & $1.27: 1$ \\
\hline 2010 & 32960 & 18713 & $1.39: 1$ \\
\hline 2011 & 28516 & 22386 & $1.49: 1$ \\
\hline 2012 & 31532 & 22593 & \\
\hline 2013 & 34508 & 23160 & \\
\hline
\end{tabular}

Source: Author's calculation based on UNCTAD (different years) World Investment Report, New York and Geneva: UN. 
Although there were the significant slowdown and decrease in both international trade flows and investment flows in the period of the 2008 world economic and financial crisis (Figure 1 and Figure 2), the same tendency in the relation of the forms of international trading (Table 1) can be observed in the period after the crisis as in the period before. After a fall in 2009 to 30 trillion, the sales of foreign affiliates increased worldwide to 33 trillion USD in 2010 and to 34 trillion USD in 2013, while world export increased from 15 trillion USD in 2009 to 23 trillion USD in 2013. The main channel of trading continues to be in the form of sales through foreign affiliates which significantly surpass classic, cross-border export (Figure 3).

Figure 3: Exports and foreign affiliates'sales (billion USD)

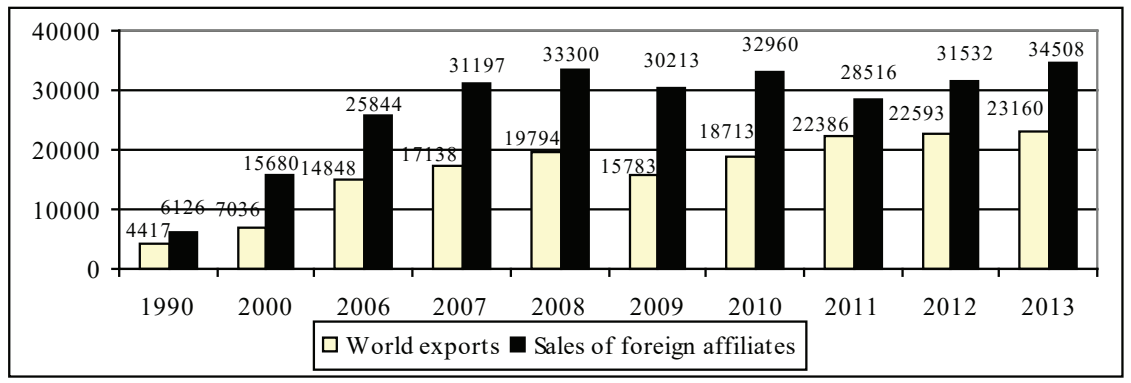

Source: Author's graphic presentation of the data from Table 1.

The post-crisis period has brought the recovery of both international trade flows and international investment flows and their higher levels. These developments haven't changed the fact that the same as in the period before the crisis, international trade flows continue to perform increasingly more through investments flows, that is through foreign affiliates which are results of foreign direct investment flows, then through classic, crossborder trade. Therefore, the sales through foreign affiliates remain the main channel of international trading.

Analysis of the international trade flows and investment flows of the groups of countries (developed and developing ones) shows also the importance of the sales through foreign affiliates (through FDI) for the each group of countries as the form of trade (export or import) realization of these countries.

For developed countries it can be shown that they export more through foreign affiliates' sales than through classic, cross-border export (Stojadinović Jovanović, 2012). Developed countries, that are the largest sources of world foreign direct investments, had much larger share in world foreign direct investment outflows (71\% in 2010) than in world merchandise export (55\% in 2010). There were similar relations in previous years: in 2003 these shares were 93\% and 64.5\% (Stojadinović Jovanović, 2008b), and in $200583 \%$ and 60.1\% (Stojadinović Jovanović, 2008a), respectively. This trend of larger shares in world foreign direct investment outflows than in world merchandise export reveals the continuous importance of non-classic specific form of export (export through foreign direct investment outflows) for developed countries. It also reveals that export through outflows of foreign direct investments from these countries is the main form of export for these countries. 
For less developed countries (developing and transition countries) with the prevailing FDI inflows over FDI outflows, it can be shown that import realization is been relied more on FDI inflows than on classic import. (Stojadinović Jovanović et al., 2015). The CEE countries achieved a higher share in world FDI inflows (9.2\% in 2008) than their share in world merchandise import (7.6\% in 2008). This means that this group of countries in import rely more on FDI inflows (buying products from affiliate which is the result of FDI inflow), than on classic import which takes place across the national borders and which is registered in trade balances of countries and official trade statistic figures. This trend is not a new feature of these countries' trade flows, and it can be observed in other years. In previous period (2007 data), these countries also relied more on FDI inflows than on classic import as well as in recent period (2011 data).

These findings highlight the importance of understanding the relationship between international trade flows and investment flows. They show that there is a need for recognition of the connection and intertwining of international trade flows and international investment flows and also the apprehension of prevailing realization of international trade through foreign affiliates' sales as well as the resulting need for the international trade analysis and calculation different from the classical one. Only this approach, that means the new coverage implementation of international trade flows and inclusion of the dominant trading channel - sales through foreign affiliates, will lead to the different but real international trade values and international trade picture.

If we implement the new approach and the new way of coverage of international trade flows (Stojadinović Jovanović, 2013), we will get the new values of world trade higher than the existing official values (Table 2). Real world trade value in 2008 was 46 trillion USD, after crisis was 40 trillion USD (in 2009) and 45 trillion USD (in 2010), while in 2013 it reached almost 50 trillion USD, what is from 25 to 27 trillion USD per year more than official trade figures shows. The newly values of world trade are higher than the existing official ones in case of both pre-crisis and post-crisis period showing that the real (actual) world trade is much higher than the official figures show due to the new, prevailing form of trading - very high foreign affiliates' sales.

Table 2: New coverage of trade flows and the real world trade values (billion USD)

\begin{tabular}{|l|l|r|r|r|r|r|r|r|r|}
\hline & & 1982 & 1990 & 2008 & 2009 & 2010 & 2011 & 2012 & 2013 \\
\hline 1 & $\begin{array}{l}\text { World export (registered in } \\
\text { official trade statistics) }\end{array}$ & 2395 & 4417 & 19794 & 15783 & 18713 & 22386 & 22593 & 23160 \\
\hline 2 & $\begin{array}{l}\text { + Total sales of foreign } \\
\text { affiliates }\end{array}$ & 2741 & 6126 & 33300 & 30213 & 32960 & 28516 & 31532 & 34508 \\
\hline 3 & $\begin{array}{l}\text { - Export of foreign } \\
\text { affiliates }\end{array}$ & -688 & -1523 & -6599 & -5262 & -6239 & -7463 & -7532 & -7721 \\
\hline 4 & $\begin{array}{l}\text { Domestic sales of foreign } \\
\text { affiliates (2-3) }\end{array}$ & 2053 & 4603 & 26701 & 24951 & 26721 & 21053 & 24000 & 26787 \\
\hline 5 & $\begin{array}{l}\text { Total world export - real } \\
\text { value which covers foreign } \\
\text { affiliates' trade (1+2-3) } \\
\text { or (1+4) }\end{array}$ & 4448 & 9020 & 46495 & 40734 & 45434 & 43439 & 46593 & 49947 \\
\hline
\end{tabular}

Source: Author's calculation based on data from UNCTAD (different years) World Investment Report, New York and Geneva: UN. 


\section{Conclusion}

Our current analysis of international trade and FDI is based on the official statistical trade and FDI figures. However, the paper has shown that beside the analysis based on the official trade and FDI figures, there are mutual interconnection and intertwining of international trade flows and investment flows that also should be taken into account in the analysis of the world trade. The mutual interconnection and intertwining of international trade and investment flows can be found also in the post-crisis period as well as in the period before the crisis, only within the different values of international trade and international investments in these periods.

It is observed the recovery of both international trade flows and international investment flows and their higher levels in the post-crisis period. These developments haven't changed the fact that the same as in the period before the crisis, international trade flows continue to perform increasingly more through investments flows, that is through foreign affiliates' sales which are results of foreign direct investment flows, then through classic, cross-border trade. The sales through foreign affiliates have remained the main channel of international trading.

Therefore, the paper has accentuated the need for the recognition of this intertwining of international trade flows and international investment flows and prevailing realization of international trade through foreign affiliates' sales resulting in the need for the international trade analysis and calculation different from the classical one. The applied approach, based on the new coverage of international trade flows, has given the new international trade values and international trade picture. The results of application of the new international trade coverage are more realistic, higher values of world trade including both classic cross-border trade and foreign affiliates' sales.

Realistic trade and FDI values represent the base for policy creation and policy decision. If we look for the impetus and drivers of the economic growth in trade and investments flows, then we must take into account the connection and intertwining of these two types of flows in order to have a real picture of them and make adequate decisions in the field of investment, trade and economic policy.

\section{References}

Agarwal, J.P. (1980). Determinants of Foreign Direct Investment: A Survey. Weltwirtschaftliches Archiv, 116, 739-773.

Blonigen, B. A. (2001). In search of substitution between foreign production and export. Journal of International Economics, 53(1), 81-104.

Blonigen, B. A. (2005). A Review of the Empirical Literature on FDI Determinants. Atlantic Economic Journal, 33, 383-403.

Broadman, H. G., ed. (2005). From Disintegration to Reintegration: Eastern Europe and the Former Soviet Union in International Trade. The World Bank, Washington.

Clausing, K. A. (2000). Does Multinational Activity Displace Trade?. Economic Inquiry, 38(2), 190-205. 
Dunning, J. H. (2000). The eclectic paradigm as an envelope for economic and business theories of MNE activity. International Business Review, 9 (2), 163190.

Faeth, I. (2009). Determinants of FDI - a Tale of Nine Theoretical Models. Journal of Economic Surveys, 23 (1), 165-196.

Hufbauer, G. D., Lakdawalla, D. and Malani, A. (1994). Determinants of direct foreign investment and its connection to trade. UNCTAD Review 1994, 39-51.

Head, K. and Ries, J. (2001). Overseas Investment and Firm Exports. Review of International Economics, 9(1), 108-22.

Kojima, K. (1973a). A macro-economic Approach to Foreign Direct Investment. Hitotsubashi Journal of Economics, 14 (1), June 1973.

Kojima, K. (1973b). International Trade and Foreign Direct Investment: Substitutes or Complements. Hitotsubashi Journal of Economics, 16 (1).

Kojima, K. (1982). Macroeconomic versus International Business Approach to Direct Foreign Investment. Hitotsubashi Journal of Economics, 23 (1).

Kojima, K. and Ozawa, T. (1984). Micro- and Macro- economic Models of Direct Foreign Investment: Toward a Synthesis. Hitotsubashi Journal of Economics, 25 (1), June 1984.

Lipsey, R. E. and Weiss, M. Y. (1984). Foreign Production and Exports of Individual Firms. The Review of Economics and Statistics, 66(2), 304-08.

Ozawa, T. (1990). Multinational corporations and the 'flying geese' paradigm of economic development in the Asian Pacific. Paper presented at World Conference on Multinational Enterprises and 21st Century Scenarios, Tokyo, 4-6 July, mimeo.

Ozawa, T. (1992). Foreign direct investment and economic development. Transnational Corporations, 1, 27-54.

Ozawa, T. (1995). The flying-geese paradigm of tandem growth: TNCs' involvement and agglomeration economies in Asia's industrial dynamism. Paper presented at AIB meeting in Seoul, Republic of Korea, 15-18 November, mimeo.

Stephen, H. (1976). The International Operations of National Firms: A Study of Direct Foreign Investment. Cambridge, MA, Monographs in Economics, No. 14.

Stojadinović Jovanović, S. (2008a). Impact of foreign direct investments on trade flows. In: Transitional Challenges of EU Integration and Globalization (CD ROM with full papers, pp. 1-8). Sarajevo: School of Economics and Business in Sarajevo.

Stojadinović Jovanović, S. (2008b). Međunarodna trgovina i transnacionalne kompanije - supstitut ili dopuna. Međunarodni problemi, 1/2008, 93-115.

Stojadinović Jovanović, S. (2010). Novi pristup u analizi međunarodne trgovine. Doktorska disertacija, Ekonomski fakultet Univerziteta u Beogradu, Srbija.

Stojadinović Jovanović, S. (2012). Foreign Direct Investment Outflows: New Form of Export. Actual Problems of Economics, 9 (135), 493-499.

Stojadinović Jovanović, S. (2013). A Proposal for New Coverage of International 
Trade Flows. Actual Problems of Economics, 4 (142), 480-486.

Stojadinović Jovanović, S., Jakšić, M. and Todorović, V. (2015). FDI: Source of Financing or Source of Trade for CEE. Ekonomika preduzeća, 2/2015, 182-195.

Vernon, R. (1966). International Investment and International Trade in the Product Cycle. The Quarterly Journal of Economics, 80, May 1966.

UN (2010). International Merchandise Trade Statistics: Concepts and Definitions 2010. Geneva.

UN, EC, IMF, OECD, UNCTAD and WTO (2002). Manual on Statistics of International Trade in Services 2002. Geneva.

UN, EC, IMF, OECD, UNCTAD and WTO (2010). Manual on Statistics of International Trade in Services 2010. Geneva.

UNCTAD FDI database.

UNCTAD (2001). World Investment Report 2001. New York and Geneva: UN.

UNCTAD (2002). World Investment Report 2002. New York and Geneva: UN.

UNCTAD (2003). World Investment Report 2003. New York and Geneva: UN.

UNCTAD (2004). World Investment Report 2004. New York and Geneva: UN.

UNCTAD (2006). World Investment Report 2006. New York and Geneva: UN.

UNCTAD (2008). World Investment Report 2008. New York and Geneva: UN.

UNCTAD (2011). World Investment Report 2011. New York and Geneva: UN.

UNCTAD (2014). World Investment Report 2014. New York and Geneva: UN.

WTO (2004). International Trade Statistics 2004. Geneva: WTO.

WTO (2007). International Trade Statistics 2007. Geneva: WTO.

WTO (2012). International Trade Statistics 2012. Geneva: WTO.

WTO (2013). International Trade Statistics 2013. Geneva: WTO.

WTO (1995). International Trade - Trends and Statistics 1995. Geneva: WTO.

\section{Endnote}

3. The changes are intended in the international guidelines: Manual on Statistics of International Trade in Services 2010 (UN et al., 2010) and International Merchandise Trade Statistics: Concepts and Definitions 2010 (UN, 2010), which recommend countries to separately record products which cross borders as a result of transactions between related parties (i.e. between affiliates and their parent companies). 